\title{
HEARING IMPAIRMENTS OF ADULTS IN MTYAGI PREFECTURE
}

\author{
MASAKI NAGAFUCHI, M.D. \\ Faculty of Education, Tohoku University \\ KENICHI TAKAHASHI, M.D. \\ Sendai National Hospital
}

A survey and analysis of adults aged 18 years or older with hearing problems were conducted throughout Miyagi Prefecture from 1969 to 1973. Types of hearing losses in 2, 180 persons with the hearing loss above $40 \mathrm{~dB}$ were investigated from the epidemic standpoint.

The results were as follows:

1. The occurrence of hearing impairment was 23 men and 14 women per 10,000 population. The occurrence of hearing impairment tend to be lower in urban areas than in farming communities.

2. Hearing impairment increased with advancing age and reached its peak among people in their 70 's.

3. The main causes of hearing impairment were otitis media, aging (presbycusis), and hereditary disposition. Other causes included head trauma, acoustic trauma, pregnancy and Ménière's disease.

4. The second-born suffered comparatively fewer hearing impairment than their siblings.

5. Tinnis was seldom found in cases of hereditary hearing loss, but was frequently found in cases of hearing impairment due to head trauma, acoustic trauma and Ménière's disease.

A78-0508. 0571

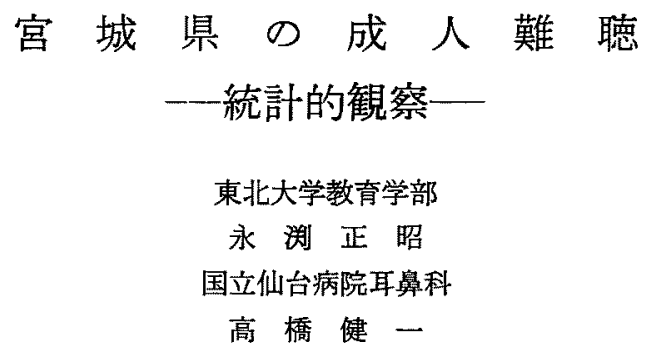

1.はじめに

難聴の原因や種類について、これまでに多くの研究が ありかなりのことは判明してきたが，難聴の発生状況 を疫学的に検討した報告は少ない

われわれは宮城県の成人難聴者（18才以上）の実態を 検討したのでこここに報告しご批判を仰ぐ次第です

\section{2. 調查方法}

宮城県総合福祉センターに身体障害者更生相談所があ り，ここで成人難聴者の検診とともに彼等の福祉行政を 行なつている. 県下の各地方に福祉事務所があつて難聴 者の状況が把握され，それをもとにして検埥を行つてい
るが，内容は難㯖の経過と家族を含めた病歷調查，聴力 検查, 補㯖器の適応検查, 身体障害者手帳の交付が主な ものである.

過去 5 年間（昭和 44 年 4 月 49年 3 月）で約 2300 名に 達しているが，このうち「良耳の平均㯖力が $40 \mathrm{~dB}$ 以上 の者」2180名について検討した，それで片側耳が正常に 近い一側高度難聴や会話音域の障害が少ない高音障害型 の難聴は除外されている．また病弱や肢体不自由のため 難聴がありながら，検診を受け得ない人もいるし，特に 農村では他県一出稼ぎに行っている人もいる。このよう な理由で, 難聴の実態を正確に把握することは困難であ 
るが，一応の傾向を知るために人口分布を加味して統計 をとつた，それで以下に述べる難聴の地域分布は各地区 の相対的な比較にはなるが，難聴の発現頻度を正しく示 していないので断つておく。

人口統計” は昭和45年の国勢調查報告を参考にしてい るが，宮城県の状況を説明すると，人口約 180 万人で その5ち約 $1 / 3 か ゙$ 仙台市とその周辺都市に集中し，残りが 地方に分散している. 地理的には，東部は太平洋に面 し，特に塩釜から気仙沼にかけては三陸海岸で漁業が盛 んである、西部は奥羽山脈を境に山形県と接しており農 業と林業が営まれている。そして重工業は少なく農業が 中心で，仙台市を除けば人口移動は比較的少ない地域で ある.この地域性を考慮して次の 4 地区に分けた（図 1).

1. 仙台地区：仙台市を中心としてその周辺都市（名 取，泉，多賀城各市）を含めた地域

2. 海岸地区：塩釜，石巻，志津川，気仙沼を含む三 陸海岸に沿った地域

3. 北部：仙台より北部の農山村

4. 南部：仙台より南部の農山村

\section{3. 調查結果}

18 才以上の成人難聴者は2180名（男1356名，女824名） で，これを地域別にみたのが図 2 である，平均すると男 1 万人に対して23名，女は14名であるが，仙台地区が最
も少なく，北部と南部の農山村で多く，全地域共通して 男が女より多い傾向にある。

次纪宫城県全域の難聴者を年代別化比較すると図 3 の

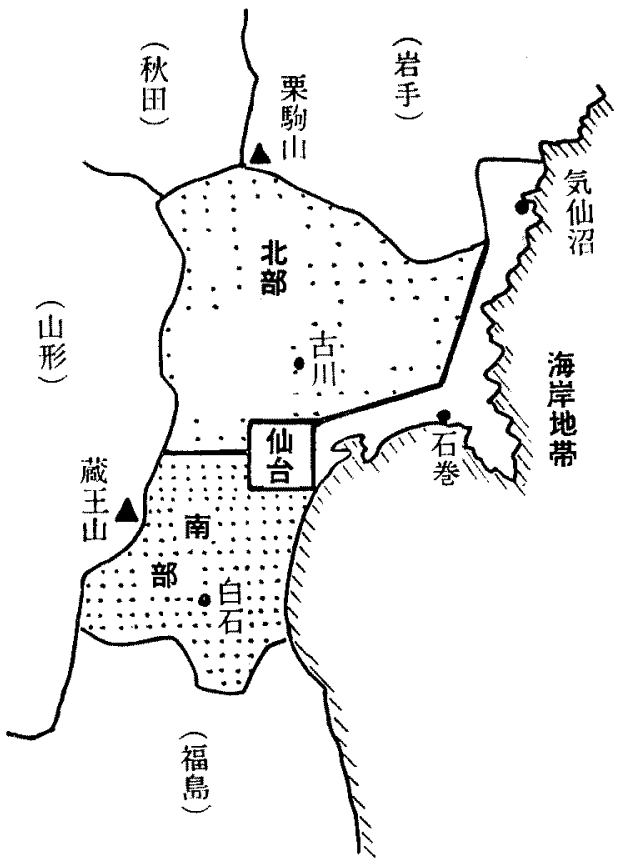

図 1 宮城県の 4 区分

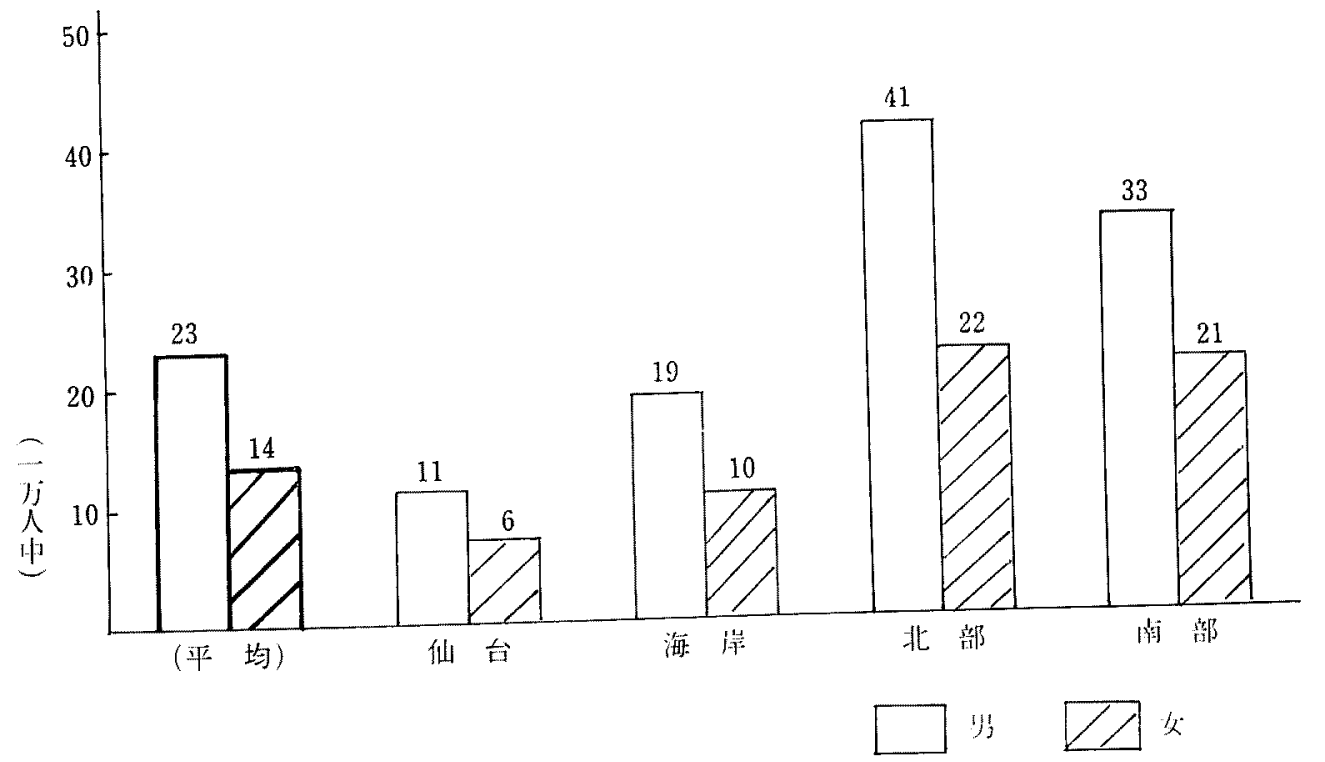

図 2 地域別の難聴者（18才以上） 


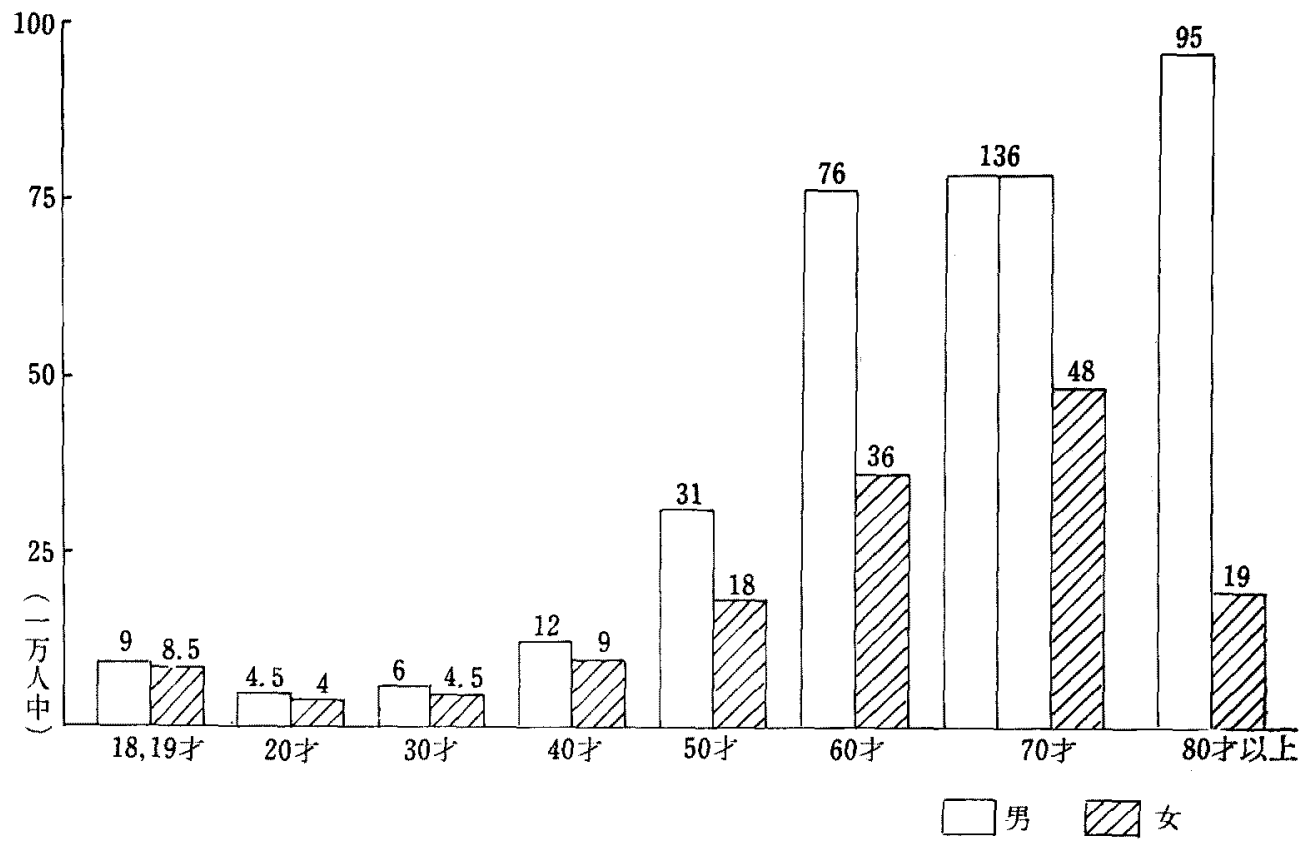

図 3 年代別の難㯖者（宮城県全域）

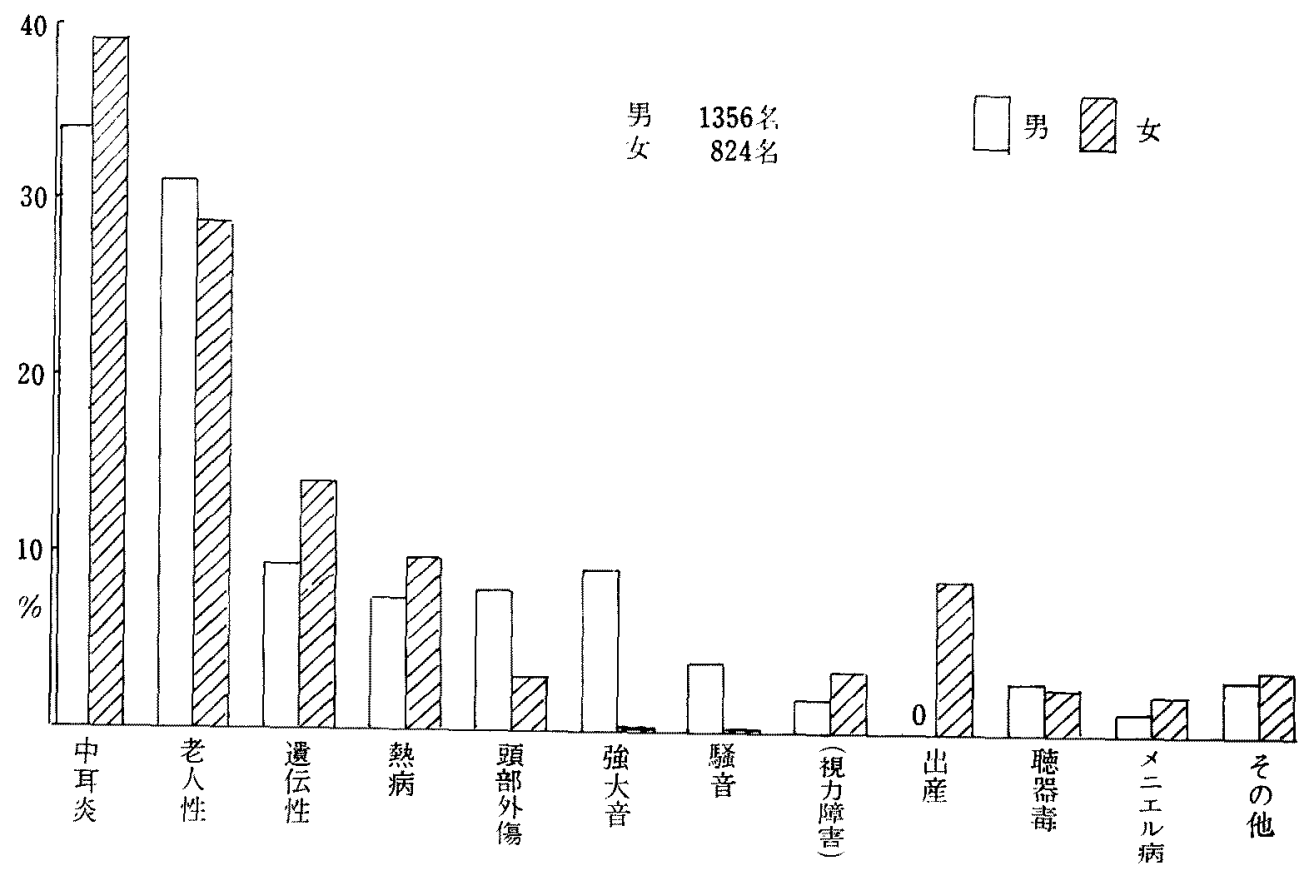

图 4 難㯖 の原因 (2180名) 
ような結果が得られた。これは各年代の男女別人口1万 人に対する比率を示したものであるが，20代で最も少な く18，19才では逆に多くなつている．これは一見矛盾し ているよらに思われるが，18．19才群は万ら学校生徒が 主であり，彼等は卒業後（20代前半）他県，主として関 東地方へ就職する者がいるので，このような結果になつ たといえる. 40代以後難聴者が徐々に增加しているが， この大部分は老人性難聴である. そして70代でピークと
なり80代社やや減少しているが，これは70代で死亡する 例が多く，80代まで生存している人で難㯖になる例は比 較的少ないことを示しているといえる.

これらの難聴について，直接, 間接の原因と考えられ るものを含めて集計すると図4のようになる。ここにあ げたものは 1 人で重複しているものも加えているので， 全体で $100 \%$ を越す結果となつているが，これらの項目 について説明を補足しておく。
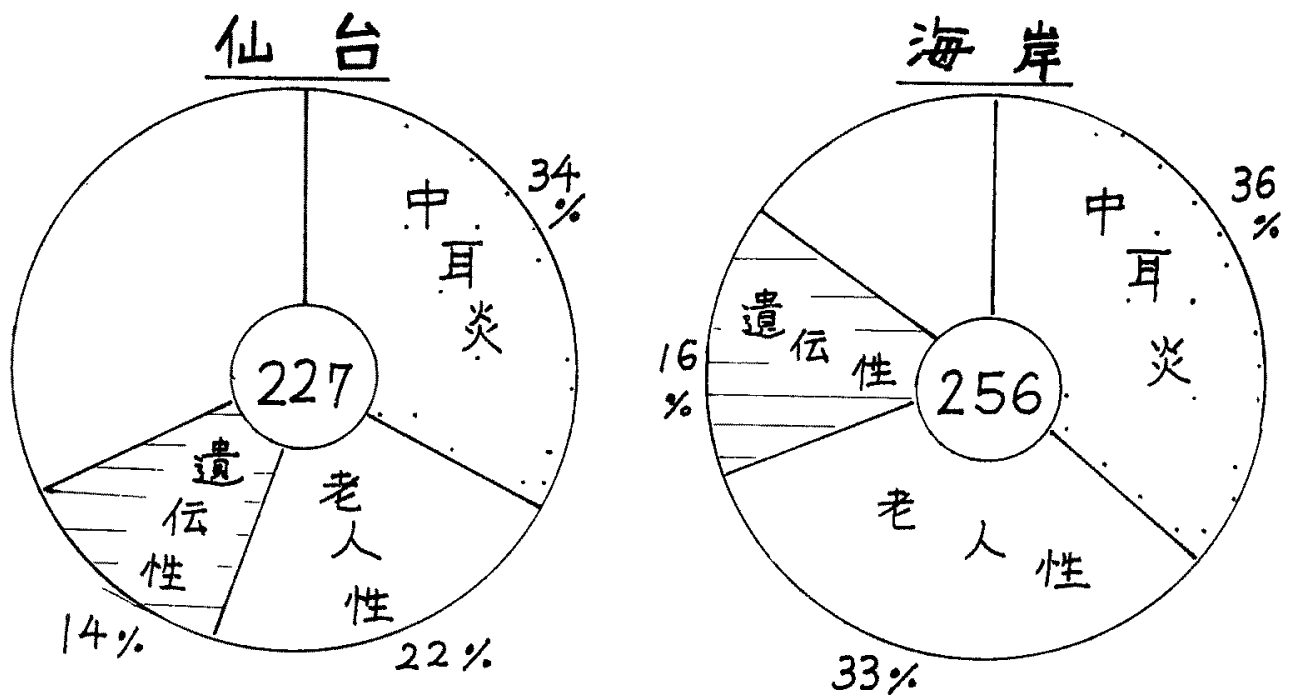

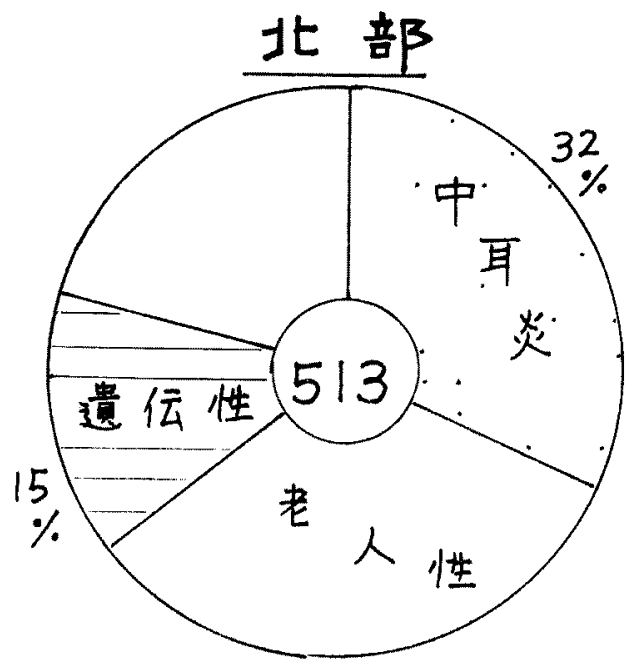

$33 \%$

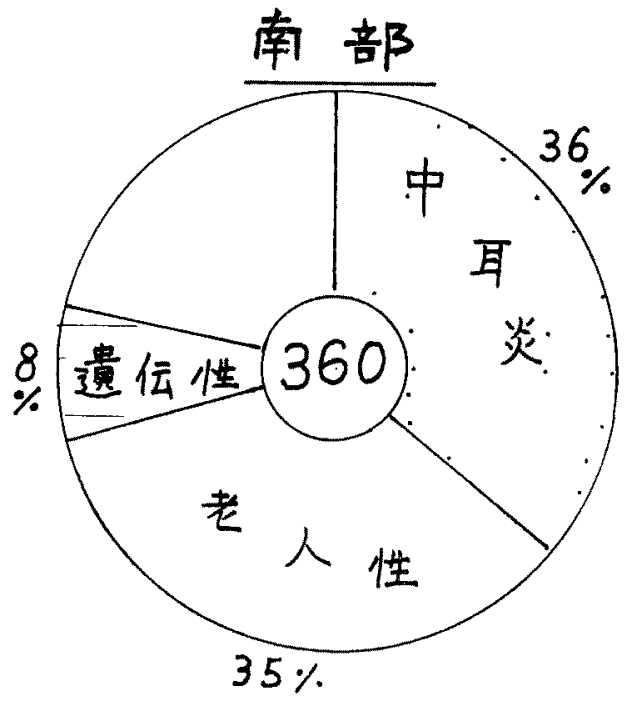

図 5 難 聴 原因の地城分布（男） 
中耳炎：現存治療を必要とするもの，以前に中耳手術 を受けたもの，治痖していても鼓膜の穿孔や強度の 癄着を残しているもの。

老人性：30才以後, 特に原因がなく徐々に難聴にな り，それが進行するもの，

遺伝性：4 親等までの血縁者に難聴者がいるもの．

熱病：高熱疾患に䍜患して，その後に難㯖になつたも の.
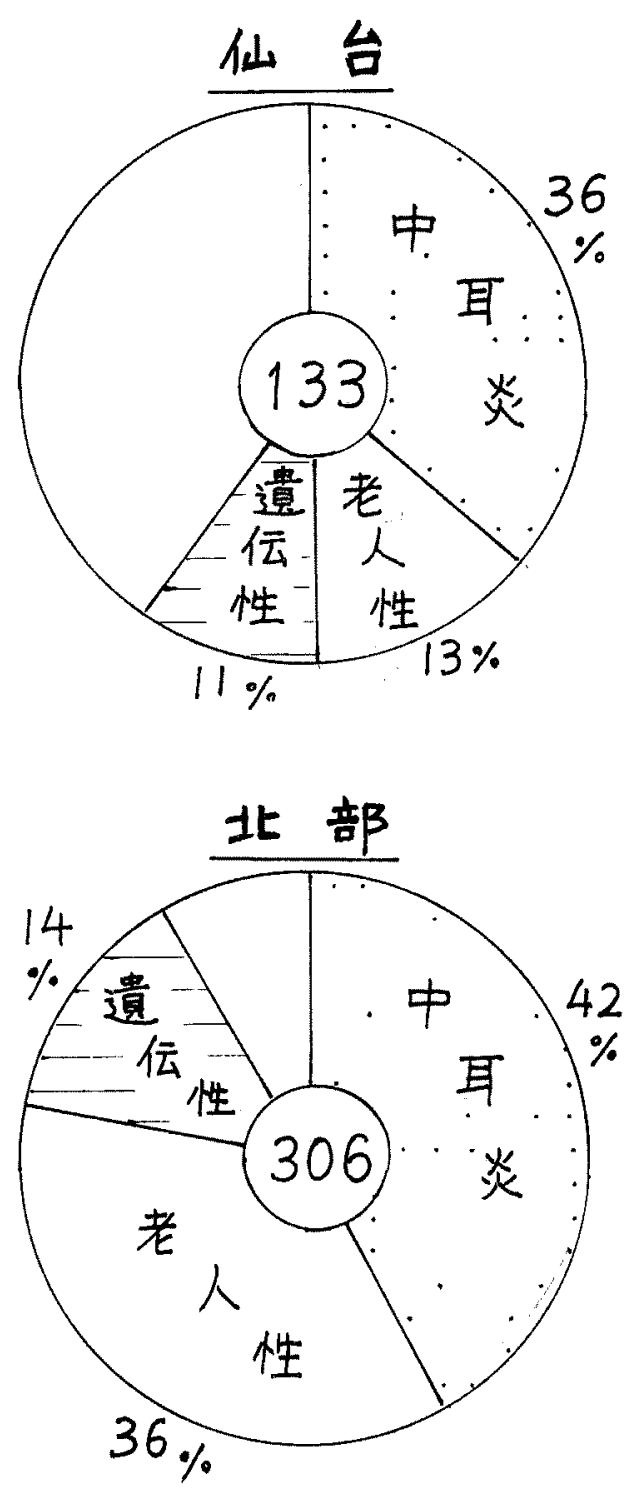

頭部外傷 : 頭の打撲，損傷で一時的にせよ意識不明に なり，入院治療を受けたもの。

強大音: 瞬間的な強大音に 1 回あるいは頻回にさらさ れたもの.

騒音 : 騒音下で長期間労墈したもの.

視力障害：これは難聴の原因といらょり合併症といら べきで，視力矯正の困難な弱視や盲を併発している bの.
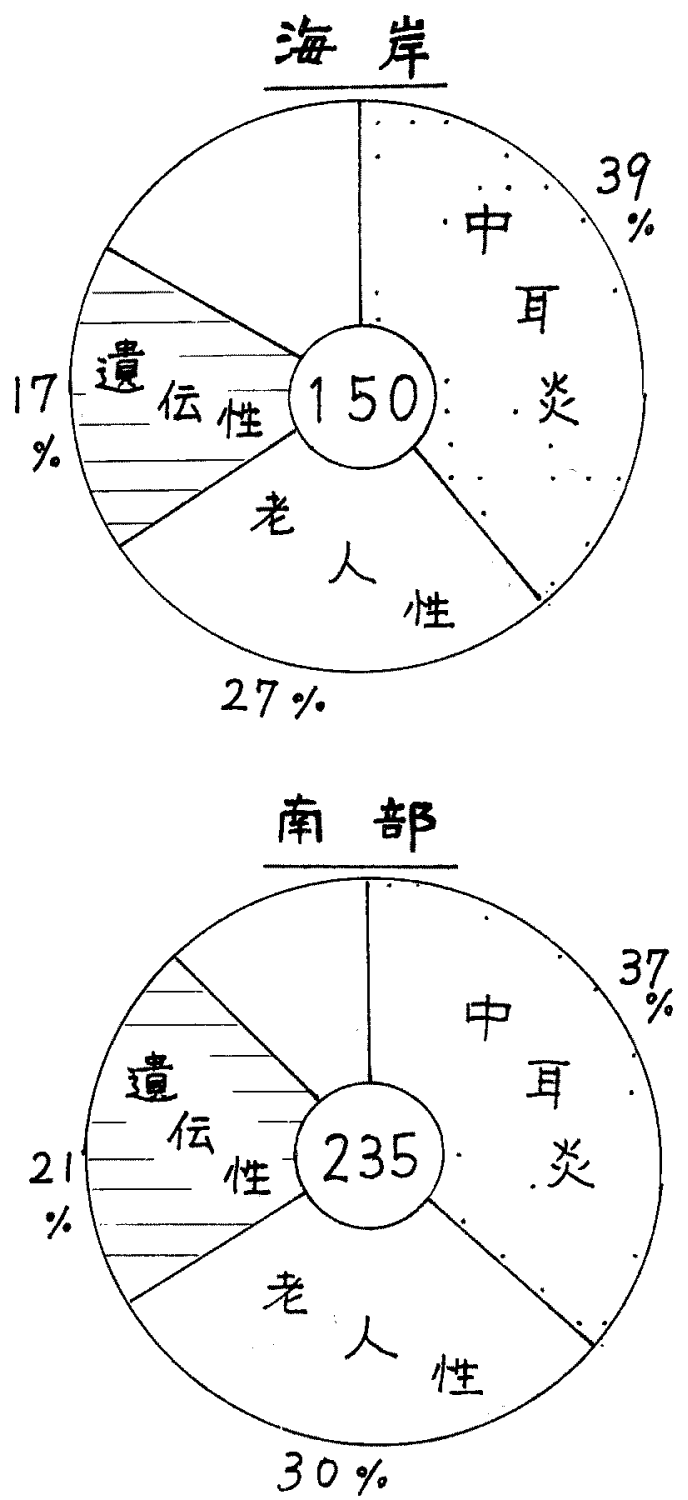

図6 難 聴原因の地域分布（女） 
出産：出産のあと難聴になつたり，難聴が進行してい るもの.

聴器毒：SM, KM などの注射を受けたもの。

メニエール病：めまい，耳鳴などと一粕に難㯖になっ たもの.

その他：突発難聴，脳卒中を始め，冒 潰瘍，副鼻腔

炎，婦人科疾患の手術後に難聴になつたもの，糖尿

病，腎炎，白血病などの内科的疾患.

以上のような観点で難㯖の原因を検討すると，中耳炎 が全体の37\%が最も多く，老人性難㯖は30\%をしめ，遗 伝性素因をもつ者が11\%である。

そこで,これら難㯖原因の主なむの3つ（中耳炎，老 人性，掼伝性）の地域別頻度を男女で比較すると図 5 , 6のような結果が得られた，各円の中央の数字はその地 城の難㯖者の数を示している。これを通覧すると，中耳 炎は全地域とも30\%台がほとんどで，男女差も特にみら

表 1 難聴者で中耳炎のある者 年代別の比率 $(\%)$

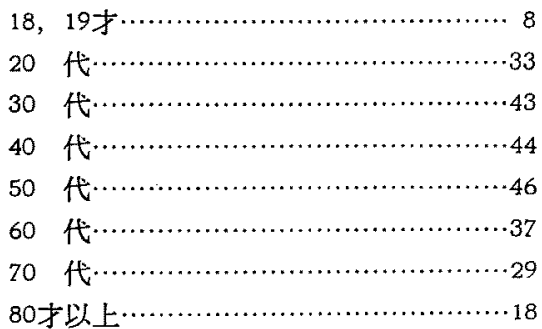

れないこれに反して，老人性難聴と遺伝性素因につい ては地域差と男女差が顕著にみられ，傾向としては仙台 地区が最も少ない

各年代の難聴者の中で中耳炎をもつ者の比率を調べる と，表1の上5に $18 ， 19$ 才で $8 \%$ と最も少なく，その後 年令とともに增加し，50代で最も多くなっている，そし て60代以後は減少しているが，これ性老人性難聴が60才 以後に多いため比率が相対的に低下したものである。こ のことから，中耳炎特に化膿性中耳炎は年とともに減少 する傾向にあるといえる。

次に難聴発現と兄弟順位の関係を検討した。まず難聴 者の兄弟数を調心゙ると，図 7 のらに 1 人から最高 12 人 までいることがわかり，その5ち4人あるいは 5 人兄弟 が最も多く6人以上は漸次少なくなつている。

そこで難聴者が兄弟のうち何番目であるかを難㯖原因 別に比較したところ，図8のような結果となつた．傾向 として2つあり，その1つは兄弟順位が進むにつれて難 聴者も減少するタイプであり，その $2 つ は 2$ 番目の者に 難聴が少ないタイプである。ここには前者の代表として 中耳炎, 老人性難聴, 後者として遗伝性と出産性の 4 つ をあげているが，聴器毒む後者に属し，音響外傷は両者 の中間で 2 番目と 3 番目の割合は近似していた，兄弟数 の頻度からすれば， 1 番目が最も多く，2番目， 3 番目 と順次減少してゆくので，難聴者の数もこの順に減少し てゆくと考えられるが，原因別にみると 2 番目が難聴沉 罹患しがたい場合のあることがわかつた。

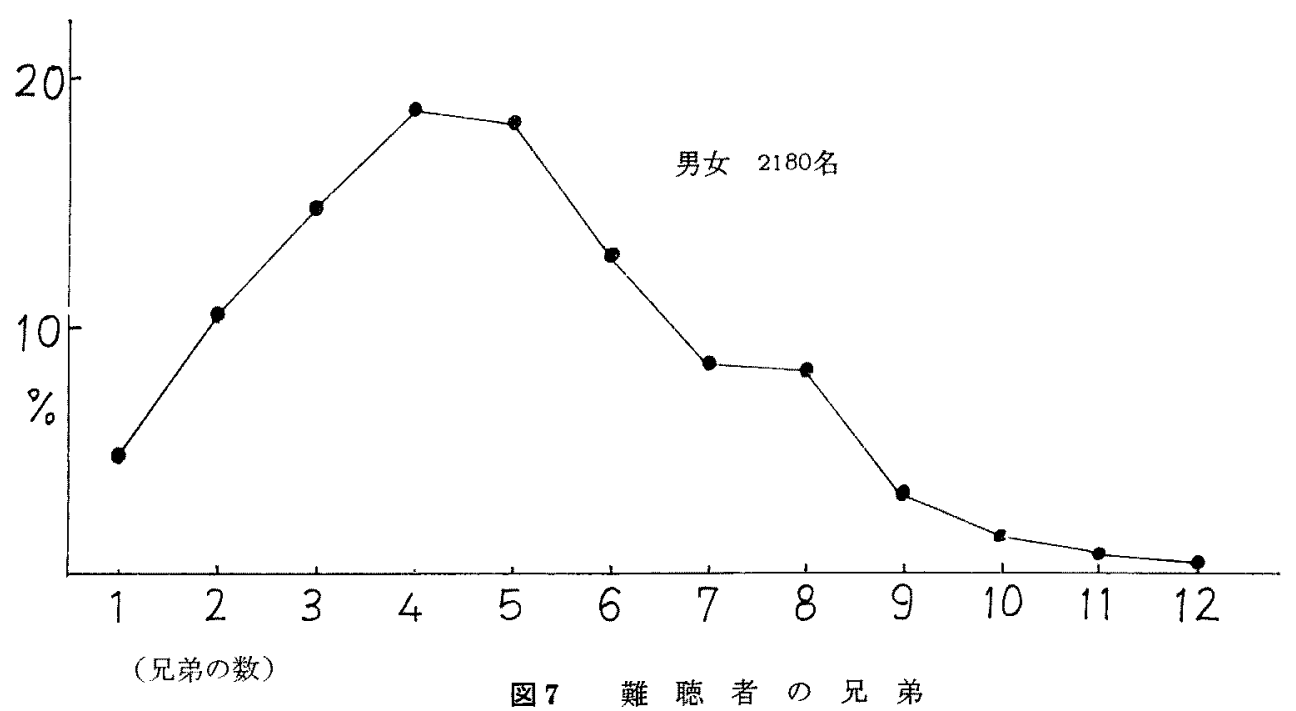


難聴者の中には耳鳴を訴える者が多いので，これを難 聴原因別に検即したのが図のである、耳鳴の詳細な検討

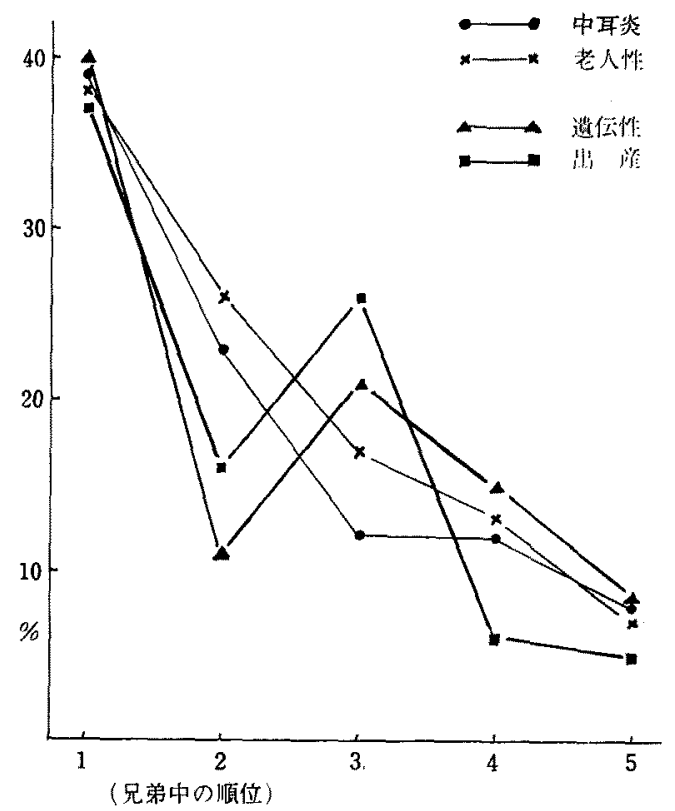

图 8 難㯖と兄弟順位の関你

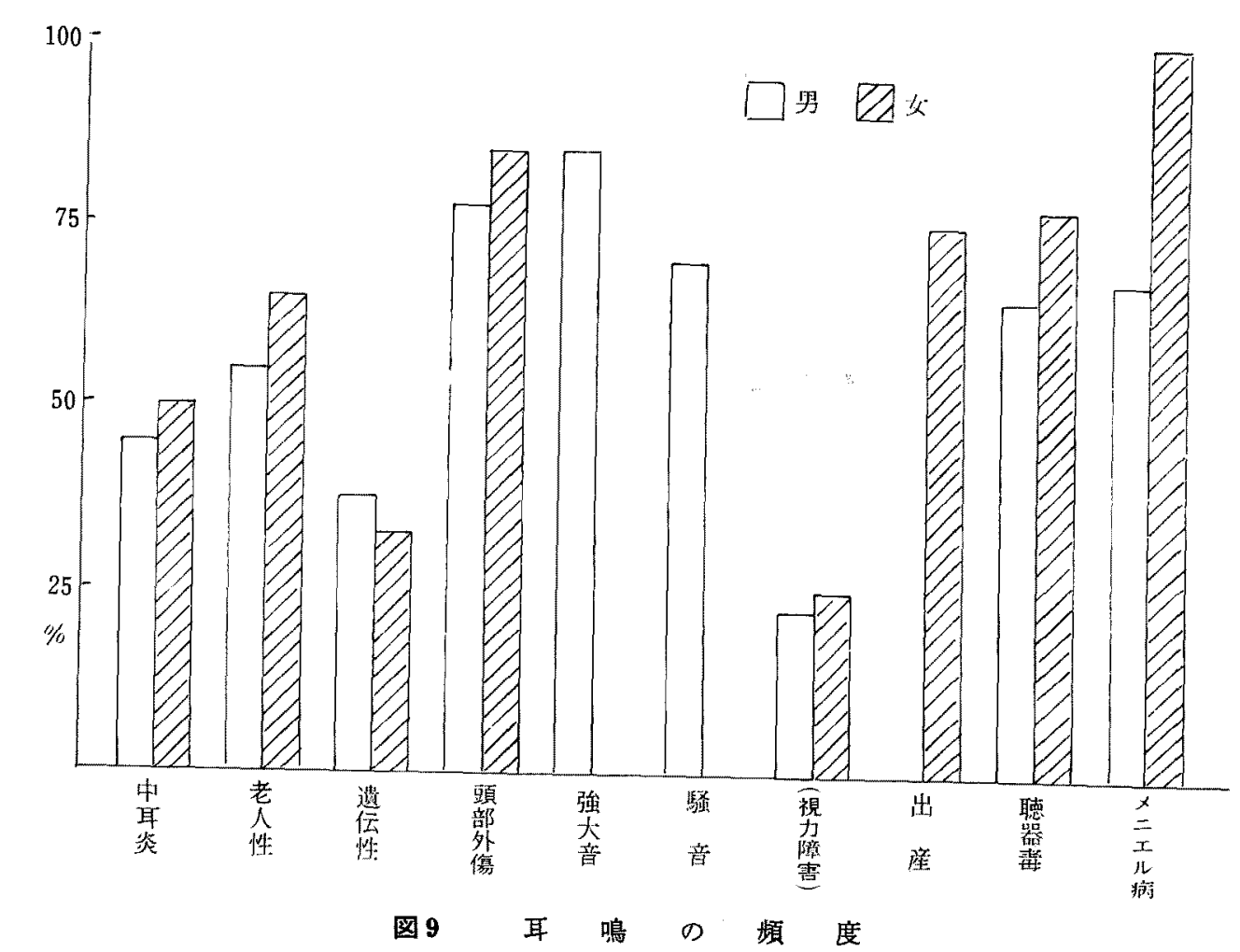

图 9 耳鳴の覑度
は省略して，耳鳴のある者だけを原因別に比較すると， 遺伝性と視力障害を伴ら者に少なく，中耳炎で約50\%老 人性で約 $60 \%$ ，その他では70\%以上にみられる，視力暲 害の中には䕗伝性である網膜色素変性も含まれているの で，それを考慮すると，遺伝性難聴は耳鳴が最む少ない といえる，これに反して頭部外傷，音響外傷，出産，聴 器毒,メニエール病など成人になってから起つた内耳性 難聴では耳鳴が謞徏度に出現していることがわかる。.

難聴者の聴力検查結果を検郡すると，両耳対称性のも のと左右差の著しいものがある。そこで左右耳の平均聴 力に $10 \mathrm{~dB}$ 以上差のあるすのを左耳と右耳で比較すると 図10のようになる，中耳炎についてみると，良聴耳が左 耳゙あるは右耳であるものがそれぞれ約 $30 \%$ にみら， 残り約 $40 \%$ は左右差なしである。これを耳科的所見と対 比すれば，中耳炎の程度とほぼ一致している。老人性と 遺伝性の難聴は両耳対称性が多く，左右差のあるものは 約20\%で，右耳の良聴がやや多いよらだが有意差はみら れない 頭部外傷では右耳難聴が多い偩向にあるが、こ れは受傷部位々関係があるかも知れぬ。しかし今回の検 診で受傷部位を明確にできた者は少ないので，その比較 は省略する，同じ音響外稘でむ強大音と騒音で受傷耳に 


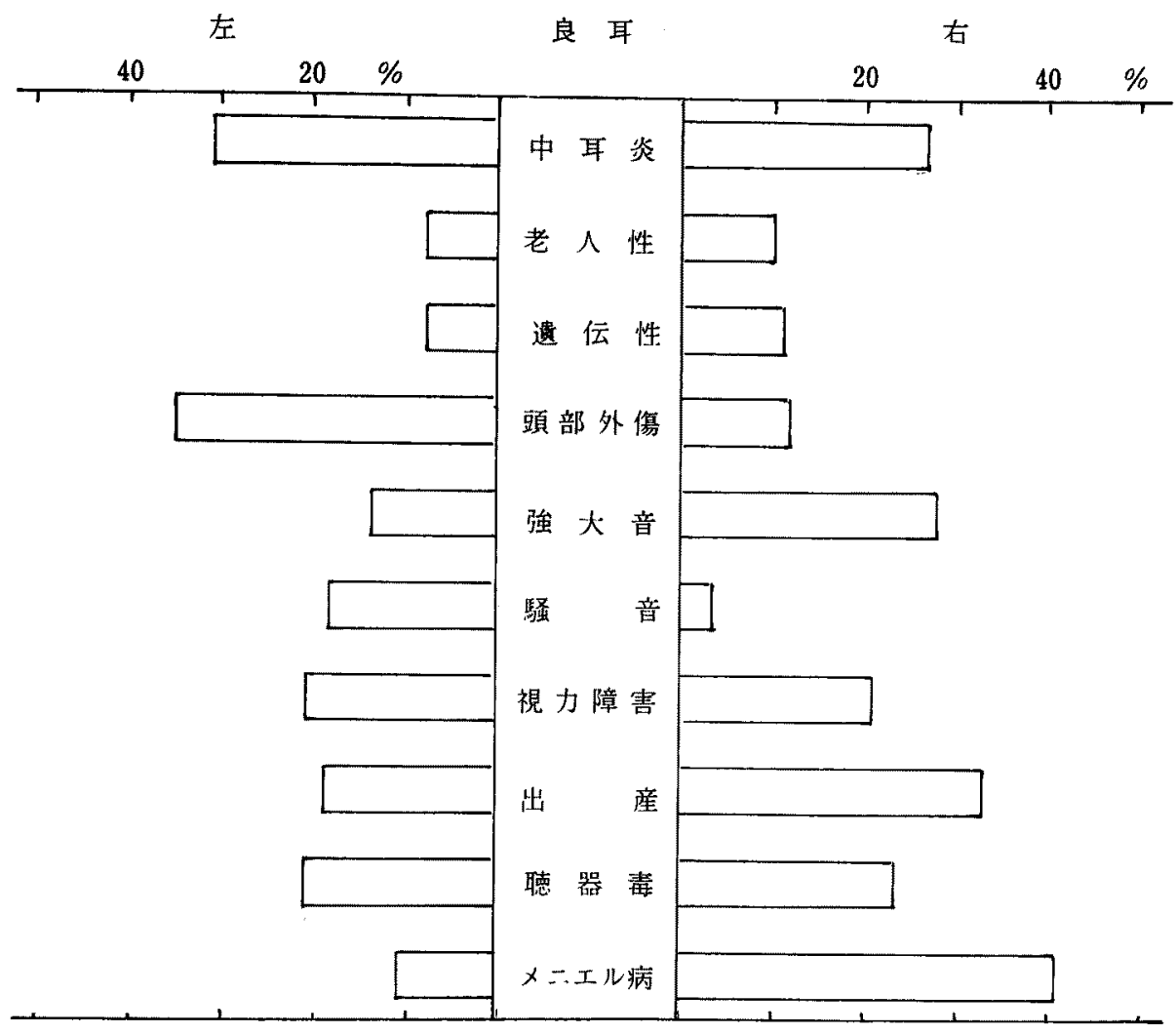

図10 聴力の左右差 (10dB以上)

差があるが，前者は兵役（戦争）で起つた者が多く，後 者は騒音下の労働從事に基因している.メニエール病は 左耳難㯖が多く現われている.

\section{4. 考察}

\section{難聘の発現}

小川次にると,「ろう」の発生頻度は人口 1 万につき スイス24人 (1870年)，オストリア14人（1890年）、ス ーデン11人 (1899年), 日本19人 (1909年)となつてい る. なた1955年 Verschuer \& Dahlberg の調査 ${ }^{9}$ では 「ろ5」の頻度は人口 1 万につきアメリカ 8 人, ドイッ 7 人, スェーデン 9 人, 日本16人であり, 正確な比較は できないが，19世紀末上り多少減少しているように思わ れる，立木他》は盛岡市内全小学校生徒の集団聴力検查 の結果, 約 $2 \%$ に難聴を諗めているが,これは埾度難聴 も含まれている.

われわれの難聴検診は地域住民全員に行つたのでな く，「日常生活に支障をきたしている難聴者」を対象に し，特に平均聴力が $60 \mathrm{~dB}$ 以上の人には身体障害者手帳 $\mathrm{I}$
を交付するのを目的としているため高度難聴者が圧倒的 に多い 過去 5 年間の調查で宫城県全域の難聴者の実態 を正確に把握したとは考えていないが，「良耳の平均聴 力が $40 \mathrm{~dB}$ 以上の難聴者」は2180名 (男 1356名, 女 824 名）であり，これは官城県人（18才以上，男女別） 1 万 人に対して男23人，女14人の比率になっている，正確な 調査をすれば，この比率は多少増加すると思われる。

ヨーロッパの「ろら」の発生頻度について, Mygind ${ }^{5)}$ は 1 万人につき平均7.265人であるが，スイスで24.5人， オランダで3.35人と, 山地が平地より多いことを報告し

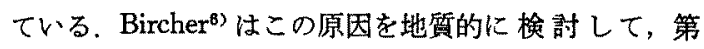
2 , 第 3 期層の塩水層を有する土地に「ろら」が多発 し，原始層，第 4 期層の淡水層の地方には少ないと述心 ている、Schwartz? は高山地带の「ろう」は甲状腺腫を 伴らものが多いと指摘している。

宮城県を大きく都市（仙台市とその周辺），海岸地带 (三陸海岸で漁業中心), 農山村の 3 地区に分けると，難 聴者は都市で少なく，ついで海岸地帯であり，農山村で 
最も多くなつている．内容的には農山村で老人性難聴と 遺伝性難聴が他地区上り多、傾向にあるが，農山村は都 市に比較して 60 才以上の老人が多いので，この点も考慮 せねばならぬ。

花田他 ${ }^{8)}$ は感音難聴者の男女比は1.8：1で男に多い上 述べている. 今回の調查では男：女=1.6：1であり，音 響外傷や頭部外甥による難聴が男に圧倒的に多いことを 考えると，成人してから男法難聴の外因にさらされる機 会が多くなり，そのために難㯖の男女比が大きく開いて いると思われる.内田97 は，先天る5は男：女＝62： 72 , 後天万らは男: 女= $17: 12$ で, 先天万5は女に, 後 天万らは男に多いと報告し，これについて Bezold ${ }^{109}$ は， 女は胎生期に障害を受けやすく，出生後は男が諸種の疾 病に侵されやすく聴器の障害もそれだけ多いのであるう と述べている。

\section{成人難聴}

木村11は30７9才の正常と思われる男女それぞれ100 名に聴力検查を行ったところ平均聴力は $30 \mathrm{~dB}$ 以内であ つたと報告している。また設楽 ${ }^{12}$ は老人が難聴を自覚す るのは $1000 \mathrm{~Hz}$ で $30 \mathrm{~dB}$ 以上の聴力損失がある場合だと 述べている. 今回の検診でも平均聴力が $30 \mathrm{~dB}$ 以内の人 は注とんどなく，実際は $40 \mathrm{~dB}$ 以上が圧倒的であつたこ とを考えると，日常生活で支障のある難聴は良耳の平均 聴力が $40 \mathrm{~dB}$ 以上ではないかと思われる.われわれのデ 一夕を年令的にみると，30代までは1万人中10名以下で 比較的少なく，40代以後加速的に堌加しているが，これ は老人性難㯖が大部分を占めているためである。

花田他 ${ }^{8)}$ は関西の某大学病院を受診した 11248 名の感 音難聴者の統計的観察を行なつているが，年令的には20 代が最む多く，高令になるほど少なくなり，原因別には $x=$ ニール病 $14.5 \%$, 感染 $8.3 \%$ ，薬物中毒 $6.6 \%$ ，先天 万 $54.4 \%$, 音鄉外傷 $4.3 \%$, 頭部外傷 $3.9 \%$, 遗伝性 0.2 $\%$ ，原因不明 $57.4 \%$ と報告している，われわれは東北の 農村を主とした地域で出張検診したので, 老人が多い傾 向他西り，難聴原因も老人性 $30 \%$ ，熱性疾患（感染） 8.3 $\%$, 頭部外傷 $7.3 \%$, 音響外傷 $7.3 \%$, そして 遺伝性は 11\%となつている。

遺伝性難聴の占める比率は小坚難聴の場合 $11.6 \%$ (東 瀬 $\left.{ }^{13)}\right) \sim 53.4 \%\left(\mathrm{Jacob}^{14)}\right)$ と高率であるのに対して, 今 回の成人では $11 \%$ あ゙あが，これは成人が小児よりも外 因で難聴になる例が多いことを示しているといえる，小 川2》は先天万らは農業, 水産業の家庭に多く, 後天万ら は都会生活者に多いと指摘しているが，今回の調查でも
遺伝性難聴は農山村に多く現われている。

われわれの難聴者の $37 \%$ が中耳炎に痽患しており，そ のほとんどが混合難㯖であるが，性別にも地域別にも偏 りはみられなかつた。 しかも20才前に䧽患して，慢性化 している例が大多数であつた，年令的には，若年者に少 なく，高令になるにつれて増加しているが，これは医療 の普及特に抗生物質の出現で化澧性中耳炎が年少者で減 少しつつあることを示していると思われる。

難聴者の兄弟順位を調ぶると, 遺伝性や出産性, 聴器 毒 (SM)によるものなどは 2 番目の者に男女とも難聴発 現が少ないことがわかり興味深い他の疾患にもこのよ らな傾向があるのか，難㯖だけなのか今後の検討課題に したい.

\section{難聴と耳鳴}

耳鳴の成因についてはまだ不明な点が多いが，その病 因として聴器の細菌感染, 薬物中書, 外傷, 騒音, 退行 変性などが考えられる(永浜 $\left.{ }^{15}\right)$ ）村島 ${ }^{16)}$ は万5児の耳 鳴を観察して先天万らに10\%，後天ろ5に $7 \%$ の耳鳴を 認めている，古賀汿は生下時あるいは小児期に始まつた 難聴の $/ 3$ は耳鳴を訴えないと報告している. 今回の調查 で遺伝性難聴，視力障害を伴う難聴は耳鳴が約 $30 \%$ で最 も少なく，特に小児期から高度難聴であつた者にその傾 向が強くみられた。

永浜 ${ }^{15}$ は伝音難聴に $32.8 \%$ ，混合難聴に $44.1 \%$ ，感音 難聴に58.1\%の耳鳴があると述べている，われわれの調 查で，中耳炎を有する者はほとんどが混合難聴であり彼 等の $45 \%$ が耳鳴を訴えている. 切替 ${ }^{18}$ は老人性難聴で62 \%に耳鳴があると述べているが，われわれも65\%に認め ている. 頭部外傷の耳鳴について Bunch ${ }^{10)}$ は $71.5 \%$, 河村 ${ }^{20)}$ は $60.8 \%$ と報告しているが，われわれの場合性 82 \%とやや多くなっている. 騒音難聴では横山方は36.7\% と低率なのに対してわれわれは70\%と高率に認めた，聴 器毒 (SM) 難聴では70\% (永浜 ${ }^{223}$ ) 90\% (立木他 ${ }^{283}$ ) といら報告に対して，われわれの例は $72 \%$ であた，古 賀173鵈が最も高頻度にみられるものにメニエール病 と騒音難聴をあげているが，われわれの例ではメニエー ル病であり，特に女は $100 \%$ であつた。

以上のように難聴を原因別に耳鳴との関係で検討する と，過去の報告とほぼ一致している。すなるち，遗伝性 難㯖，特に幼児期より難聴が発現しているものに耳鳴は 少なく，つきに中耳炎であり，中でも伝音難聴で少なく 混合難㯖でやや多くなっている.一方， 頭部外傷, 薬物 (SM) などのよ 5 に内耳を比較的急速に 
侵した難聴で耳鳴は高頻度に出現している。

\section{聴力の左右差}

難㯖には両耳が同程度に障害されるタイプと一側㖵聴 のタイプがあるが，ここにあげている難聴者の多くは前 者のタイプで, 後者は比較的少ない.これ位良耳 $40 \mathrm{~dB}$ 以上の難聴を対象にしている関係もある，前者のタイプ でもオージオグラムをみると左右耳で多少の差があるの で，聴力の左右差（平均聴力で $10 \mathrm{~dB}$ 以上）を検討し た.

中耳炎汢片側良聴であるものが右耳と左耳ともに約20 \%で，特に左右差がないようである。老人性難聴や遺伝 性難㯖では左右差のあるものは少なく，而耳対称性の難 聴が多いといえる。

中村 ${ }^{243}$ は頭部外㑑による難聴を保討して，左右非対称 のものは65\%にみられ，その多くは側頭あるいは後頭の 受傷者であると述べている. Schucknecht 他 ${ }^{25)}$ は側頭骨 の横骨折による内耳障害の場合に聴力損失が大きいと報 告している，今回の謂查では左耳の良聴，すなわち右耳 の高度障害が多く出現しているが，受傷部位，側頭骨の 損甥など詳細な検討を行なつていないので，その理由に ついては不明である。

強大音による難聴は火器爆音 (戦争, 佩銃) によるも のであり，石耳良聴 (左耳障害) が多い，河田 ${ }^{26)}$ はカ一 ビン銃の射摮演習の時射手の右耳で約 115 ホン，左耳で 約 110 ホンの音が出ると指摘し, 同じ爆音にさらされる 場合でもそれを予期するとしないでは障害の程度に差が あり、これは音響性耳小骨筋の作用によると述べてい る.この考えによると，多くの人は右手利きであり，右 側の音源に対しては注意するが，左側のそれには不注意 になりがちなため左耳の障害が大きく現われたのではな いかと推察される。

これに対して，騒音工場で長期間労働した人に起る騒 音性難聴は, 強大音と逆に左耳良㯖 (右耳障害) が比較 的多〈現われている. 竹内 27 性鉣山労働者 372 名の聴力 検查を行つて，173 名に難㯖を認め，その5ち67名（39 \%) が左右非詨称であり，オージオグラムのタイプによ つて右耳障害の大きいものと左耳障害の大きいものがあ ると述べている，メニエール病では左耳難聴が多くなつ ているが，その理由は不明である。

今回の調查では左右対称性の難㯖が大部分であるが, 左右差のあるものもみられ全体的には左耳で高度難聴が

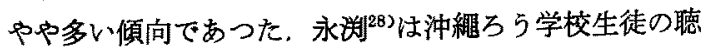
力検查でほとんどが左右対称性であるが非対称性のもの
では右耳が高度難聴である例が少し多かつたと述べてい る、これは補㯖器の装用と関係しているかも知れぬ. 左 右非対称の難㯖については，環境，外䂓などの外因の左 右差と同時に聴器の受傷性の左右差も孝えられるが，ま だ十分な説明をするにはいたつていない．

\section{5. 結論}

宮城県の成人難聴者（良耳の平均聴力が $40 \mathrm{~dB}$ 以上） 2180 名を 4 地区 (都市, 海岸, 農山村の北部と南部) に 分けて，難聴の実態を統計的に観察した.

その結果，次のことがかかつた。

1.人口 1 万人に対して難聴者は平均して男 23 名, 女14 名であり，都市に少なく，㹃山村に多、

2. 年令的には 20,30 代で少なく，70代で最も多くなつ ている.

3. 難聴原因の主なものは中耳㷋 $37 \%$ ，老人性 $30 \%$ ，遗 伝性11\%である。その他に頭部外傷, 音響外傷は男に 多く，女では出産後の難㯖が目だつている、

4. 中耳炎㹥性別にも地域別にもその頻度に偏りはない が，年令的には若年者に少ない，老人性難聴は都市に 少なく農山村に多くなつているが，これは人口棈成に も関係していると思われる，遗伝性難聴は都市に少な く農山村に多くなつている。

5. 遗伝性，出産性の難聴発現は兄弟の5 万第 2 番目の 者に比較的少ない。

6. 耳鳴遗伝性難聴に少なく，ついで中耳炎，老人性 難聴であり，メニエール病，頭部外傷，音㮣外稘など に高頻度にみられた。

7. 聴力の左右差は難聴の種類によつて異なるが，多く 恃左右対称性であつた。

\section{参考文献}

1) 昭和45年 (1970) 国势調管報告.

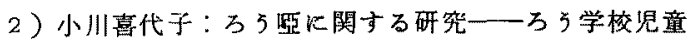
生徒の統計的钼察—, 耳喉, 33；951-963，1961.

3) Verschuer \& Dahlberg の調查. 大谷勝巳他, 万 教育科学, $8 ； 12-20,1960$.上り引用.

4) 立木孝他：学童難聴の成因に関す西研究. 日耳鼻, 77 ; 総会抄䟿, $33,1974$.

5 ) Mygind：日本耳奥㸶喉科全畫，臨床篇「万5亞」， p. $161,1953 . よ り$ 引用.

6) Bircher 同

7) Schwartze 同

8）花田力他：感音系瑾聴の統計的観察。日耳亪，65； $43-48,1962$. 


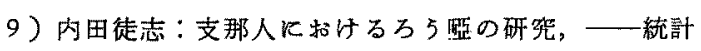
的研究一日耳䅴, 34;378-469, 1928.

10) Bezold, E.: Lehrbuch der Ohrenheilkunde, Wiesbaden S. 318, 1960.

11）木村淑志：聴覚の年令的变化. 日耳-菌，75；170190, 1972.

12）設楽哲也：日本人高令者の聴力以関す公研究，日耳: 奥, $63 ; 1551-1566,1960$.

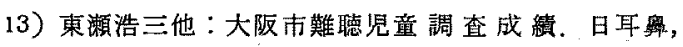
$67 ; 118-127,1964$.

14) $J a c o b, D$.: Changing aspect of deafness in school age children. Arch Otolaryng. $86 ; 166-171,1967$.

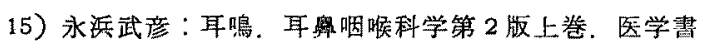
院. 258-266, 1968.

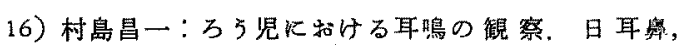
59 ; 1453-1457, 1956.

17）占賀磨次郎他：耳鳥のない感音性難聴の統計的钼 察. Audiol. Jap. 16;70-76, 1973.

18）切替一郎：眩最々耳鳴. 臨床内科小児科，11；1135$1146,1956$.

19) Bunch, C.C.: Diagnosis of occupational or traumatic deafness. Laryngoscope, 47 ; 615-691, 1937.

20) 河村進市他：頭部外㑑飞上万㯖覚障害の臨床的研 究. 日耳算, $67 ; 404-405,1964$.

21）横山俊彦：騒音性難聴以関する研究，日耳鼻，65； $1325-1342,1962$.

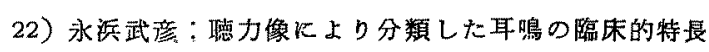
について。目雷，60；1435-1445，1957.

23）立木孝他：カナマイシンに上る聴覚障害の臨床的研 究。日耳率，71；261-272，1968.

24）中村英樹：頭部外鹪火上万㯖覚障害の臨床的研究. 日耳索，72；1605-1627，1969.

25) Schucknecht, M.F. and Davison, R.C. ; Deafness and vertigo from head iniury. Arch. Otolaryng. 63 ; $513-528,1956$.

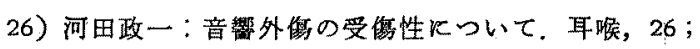
$575-585,1954$.

27）竹内利明：騒音性難㯖飞関する研究，特に左右差に ついて. 日耷鲎，76；139-154，1973.

28）永测正昭：万弓坚の失官原因および聴力について。 覀粗, $14 ; 256-263,1968$.

䜽文の要旨は，日本耳鼻咽喉科学会東北地方会第 160 回例会㸝上び第19回日本オージオロジー学会総会で燀表 した。

稿を終るにあたり，今回の調查にこ協力をいただいた 宮城罢総合福社せンターの岡田昌一館長怙上び心身障害 更生課の今田拓, 北沢重治，白旗迪子各氏飞深く感謝の 意を表します

（原稿受付 昭和49.9.5日） 